\title{
IAEA-Assisted Treatment of Liquid Radioactive Waste at the Saakadze Site in Georgia
}

\author{
Giorgi Nabakhtiani ${ }^{1}$, Irma Giorgadze ${ }^{2}$ and Michael I. Ojovan ${ }^{3, *(D)}$ \\ 1 Department for Radioactive Waste, Nuclear and Radiation Safety Agency, \\ 200 Mikheili Tsinamdzghvrishvili St, Tbilisi 0112, Georgia; giorgi.nabakhtiani@gmail.com \\ 2 Department of Engineering Physics, Georgian Technical University, 68, Merab Kostava St, \\ Tbilisi 0160, Georgia; irmagiorg@gmail.com \\ 3 Department of Materials Science and Engineering, Faculty of Engineering, University of Sheffield, \\ Sheffield S1 3JD, UK \\ * Correspondence: m.ojovan@sheffield.ac.uk
}

check for updates

Citation: Nabakhtiani, G.;

Giorgadze, I.; Ojovan, M.I. IAEA-

Assisted Treatment of Liquid

Radioactive Waste at the Saakadze

Site in Georgia. Processes 2021, 9, 1679.

https://doi.org/10.3390/pr9091679

Academic Editor: Victor Ioannovich Malkovsky

Received: 7 August 2021

Accepted: 16 September 2021

Published: 18 September 2021

Publisher's Note: MDPI stays neutral with regard to jurisdictional claims in published maps and institutional affiliations.

Copyright: (c) 2021 by the authors. Licensee MDPI, Basel, Switzerland. This article is an open access article distributed under the terms and conditions of the Creative Commons Attribution (CC BY) license (https:// creativecommons.org/licenses/by/ $4.0 /)$.

\begin{abstract}
Saakadze site in Georgia was treated using a modular type facility with apparatuses encased in three metallic $200 \mathrm{~L}$ drums using as purification method the sorption/ion exchange technology. The main contaminant of water in the underground tank was the long-lived radionuclide ${ }^{226} \mathrm{Ra}$. The casing of processing equipment enabled an effective conditioning of all secondary waste at the end of treatment campaign which resulted in the fully purified water stored on site for further reuse or discharge, and three $200 \mathrm{~L}$ metallic drums with cemented radioactive waste which are currently safely stored.
\end{abstract}

Keywords: treatment; liquid radioactive waste; sorption; ion exchange; purification; conditioning

\section{Introduction}

Nuclear waste management has received considerable attention due to the important link between the safe management of radioactive waste and public acceptance of nuclear facilities and peaceful applications of nuclear energy. Radioactive waste management is typically divided into predisposal and disposal steps, where predisposal comprises all the steps in the management of radioactive waste from its generation up to disposal. The predisposal includes processing technologies that are primarily intended to produce a wasteform that is compatible with the selected or anticipated disposal option and complies with established waste acceptance criteria [1]. Liquid radioactive waste is highly mobile, and its storage is associated with hazards from potential leakages and contamination, so it cannot be considered passively safe. International disposal standards prescribe only solids as being acceptable forms for disposal facilities [2]. Consequently, liquid radioactive waste is typically processed to decrease the waste volume, solidifying the treated waste (typically a sludge) using durable wasteforms such as cements [3]. Treatment of aqueous waste separates it into two streams: a small volume fraction of concentrate containing the bulk of radionuclides and a large volume of water which has a sufficiently low level of contamination to permit discharge to the environment or recycling. Effective liquid treatment separates as much as of the radioactive contaminants as possible from the primary waste in the concentrated fraction, which typically requires conditioning prior to storage and disposal. A flow chart for managing aqueous radioactive waste is given in Figure 1.

The radioactive waste packages produced after treatment and conditioning contain the solidified waste and are then stored in a passively safe condition pending a disposal route becoming available. 


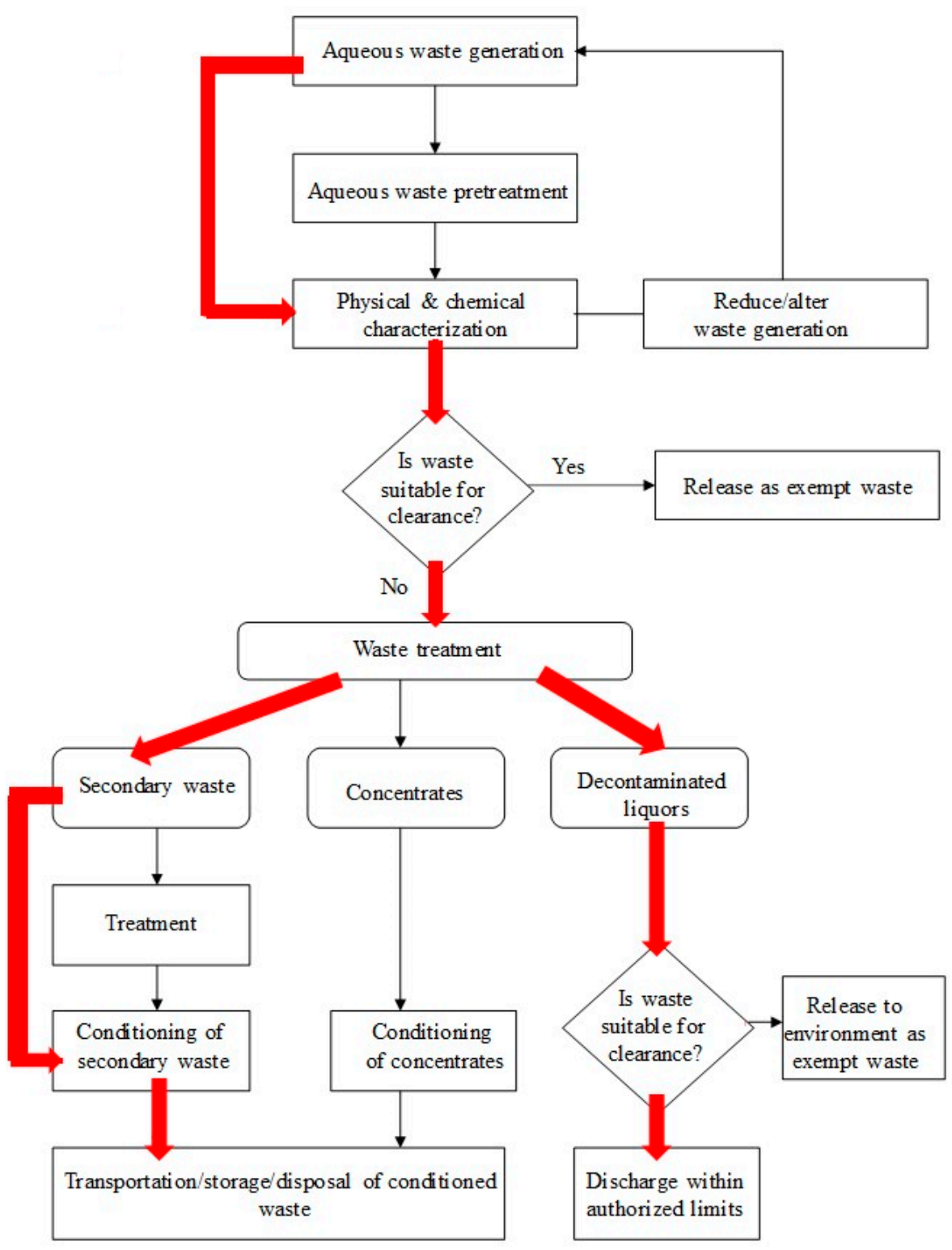

Figure 1. Management roadmap of aqueous radioactive waste following [1] with pathway utilized in the current work shown by red arrows. Reproduced with permission of IAEA.

In recent decades, Georgia has taken active measures for developing a national system for radioactive waste management, including a national strategy for radioactive waste management for the period from 2017 to 2031 that was officially adopted in 2016. The strategy is focused on the predisposal management of radioactive waste and sets six main goals. The first goal of the strategy considers location of all radioactive waste facilities on one site that is properly selected and licensed. Many investigations were conducted to identify such a site within the country. Based on the results and the legacy of former nuclear activities [4], including the "Radon" type facility which operated nearby in the past, the government of Georgia took the decision to define the s.c. Saakadze site as the preferred location. The detailed site investigation and assessment started several years ago with projects supported by Sweden's Radiation Regulatory Authority (SSM) and the European Union (EU) as well as by the International Atomic Energy Agency (IAEA). Special attention was paid within these projects to the legacy liquid radioactive waste underground tanks on the Saakadze site, which were an historical remnant from the past operations of the national "Radon" central radioactive waste storage facility. The investigation showed that about $50 \mathrm{~m}^{3}$ of the legacy aqueous waste stored in these tanks has been contaminated by long- 
lived radionuclide ${ }^{226} \mathrm{Ra}$. Thus, a significant part of activities dealt with characterization and processing of legacy liquid radioactive wastes on the Saakadze site, particularly with assistance from the IAEA.

The aim of this paper is to describe the works completed under IAEA assistance on the Saakadze site in Georgia to treat and condition the legacy liquid radioactive waste, which has resulted in an increased safety of on-site storage of conditioned waste, and will enable its safe disposal on this site.

\section{Liquid Radioactive Waste Characterization}

Three liquid radioactive waste underground tanks are situated on the Saakadze site some $30 \mathrm{~km}$ from the capital of Georgia, Tbilisi. It is important to emphasize that all documents describing site conditions and its facilities were completely lost during the civil war in the country during the 1990s. The first investigation of the site was conducted jointly by local and SSM specialists who identified the presence of contaminated water in the first of the three underground tanks. The detailed investigation of the tanks was conducted within the EU project G.4.01.08, including identification of tank dimensions and containments [5]. Figure 2 presents a schematic of the orientation of the tanks, their sizes, design and construction materials.

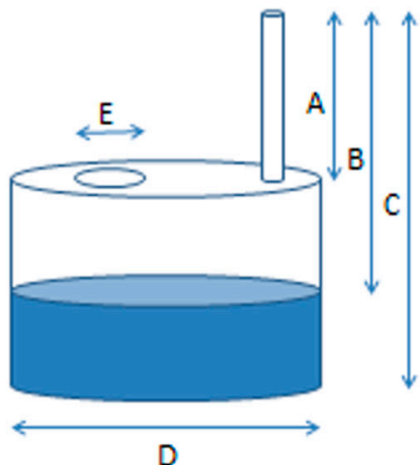

\begin{tabular}{|l|l|l|l|}
\hline Meters & Tank 1 & Tank 2 & Tank 3 \\
\hline A & 3.15 & 3.15 & 3.15 \\
\hline B & 5.2 & 5.65 & 5.4 \\
\hline C & 5.85 & 6.15 & 6.15 \\
\hline D & 7.8 & 9.5 & 9.5 \\
\hline E & 0.75 & 0.75 & 0.75 \\
\hline
\end{tabular}

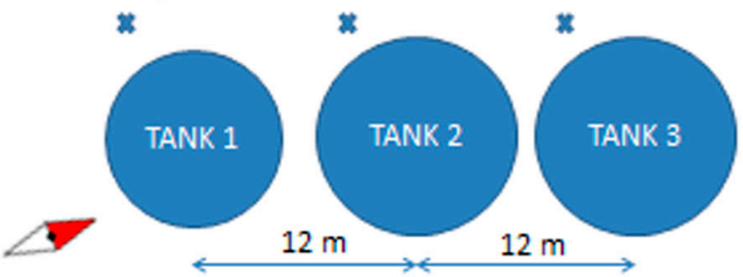

* Former filling equipment (pipe), distance from pipe to Center of each tank is approximatly 7 meters

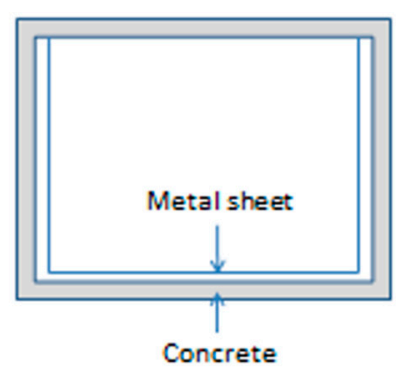

Figure 2. Schematic of liquid radioactive waste underground tanks at the Saakadze site, Georgia.

It was estimated that the volume of contaminated water in the first tank is about $41.5 \mathrm{~m}^{3}$. Samples of contaminated water from the tank were analyzed and several radionuclide contaminants were found, among which the long-lived ${ }^{226} \mathrm{Ra}$ had the highest concentration (Table 1). Water sampling was from the bottom of tank. Five samples taken contained $20 \mathrm{mg} / \mathrm{L}$ of suspended particles, although their chemical and dispersed composition were not analysed. Unfiltered water was analyzed, and Table 1 gives data after averaging of the results obtained.

In line with Georgian legislation and established clearance level for liquids, which specifies for ${ }^{226} \mathrm{Ra}$ that the discharge can be done at its concentrations in water below $10^{3} \mathrm{~Bq} / \mathrm{kg}$ [6], the given contaminated water is assigned as radioactive waste, with ${ }^{226} \mathrm{Ra}$ as the main contaminant. 
Table 1. Concentration of radionuclides in the water stored in the first underground tank.

\begin{tabular}{ccc}
\hline Radionuclide & Activity, Bq/kg & Measurement Error, $\%$ \\
\hline${ }^{22} \mathrm{Na}$ & 3.1 & 43 \\
${ }^{46} \mathrm{Sc}$ & 16.5 & 49 \\
${ }^{140} \mathrm{La}$ & 5.3 & 66 \\
${ }^{155} \mathrm{Eu}$ & 16.0 & 61 \\
${ }^{214} \mathrm{~Pb}$ & 37.8 & 1.1 \\
${ }^{207} \mathrm{Bi}$ & 1.7 & 110 \\
${ }^{214} \mathrm{Bi}$ & 8.8 & 1.4 \\
${ }^{226} \mathrm{Ra}$ & 1215 & 5.2 \\
\hline
\end{tabular}

\section{Treatment of Waste}

Several well-established aqueous waste treatment methods are currently available with Table 2 summarizing their main features and limitations [3,7-19].

Table 2. Main features and limitations of aqueous waste treatment methods.

\begin{tabular}{|c|c|c|}
\hline Method & Features & Limitations \\
\hline Filtration & $\begin{array}{l}\text { Removal of suspended solids. Use as } \\
\text { polishing step after chemical treatment. } \\
\text { Use upstream of ion exchanger. } \\
\text { Backwash is possible. }\end{array}$ & $\begin{array}{l}\text { Not suitable for colloids. Need to } \\
\text { replace filter media. }\end{array}$ \\
\hline Evaporation & $\begin{array}{l}\text { High } \mathrm{DF}^{1}>10^{3} \text {. Well established } \\
\text { technology—many different designs. } \\
\text { High volume reduction factor. } \\
\text { Concentrate can be directly } \\
\text { immobilized or dried to produce a salt } \\
\text { cake. Utilized mostly as batch process. } \\
\text { Condensate may require polishing } \\
\text { depending on the activity. }\end{array}$ & $\begin{array}{l}\text { Not suitable for small volumes of } \\
\text { aqueous waste generation. Process } \\
\text { limitations (scaling, foaming, } \\
\text { corrosion, volatility of certain } \\
\text { radionuclides). High capital and } \\
\text { operating cost with high } \\
\text { energy consumption. }\end{array}$ \\
\hline $\begin{array}{l}\text { Sorption/Ion } \\
\text { exchange } \\
\text { (organics) }\end{array}$ & $\begin{array}{l}\text { DF high on low salt content }\left(10^{2}\right) \text {. High } \\
\text { DF also possible for high salt content by } \\
\text { use of specific resins. Regeneration of } \\
\text { resins possible. }\end{array}$ & $\begin{array}{l}\text { Some colloidal particles and resin } \\
\text { fines may pass straight through to } \\
\text { the treated water. Limited radiation, } \\
\text { thermal and chemical stability of } \\
\text { the resins. Resins cost. May require } \\
\text { some chemical treatment } \\
\text { before conditioning. }\end{array}$ \\
\hline $\begin{array}{l}\text { Sorption/Ion } \\
\text { exchange } \\
\text { (inorganics) }\end{array}$ & $\begin{array}{l}10<\mathrm{DF}<10^{4} \text {. Chemical, thermal and } \\
\text { radiation stability better than organic } \\
\text { ion exchangers. Relatively easy } \\
\text { immobilization. Mostly used as once } \\
\text { through cycle. }\end{array}$ & $\begin{array}{l}\text { Some colloidal particles and sorbent } \\
\text { fines may pass straight through to } \\
\text { the treated water. Possible high cost } \\
\text { for specific sorbents. }\end{array}$ \\
\hline Microfiltration & $\begin{array}{l}\text { Removal of fine particulates. Pore sizes } \\
\text { range from } 0.05 \text { and } 5 \mu \mathrm{m} \text {. Low } \\
\text { pressure operation ( } 100-150 \mathrm{kPa}) \text {. High } \\
\text { recovery ( } 99 \%) . \text { Low fouling when air } \\
\text { backwash is employed. Mostly used as } \\
\text { the first step in treatment. }\end{array}$ & $\begin{array}{l}\text { Used for suspended fine particles, } \\
\text { but not colloidal matter. Backwash } \\
\text { frequency depends on solids } \\
\text { content of waste stream. Short } \\
\text { lifetime of organic membranes. } \\
\text { Inorganic membranes exhibit } \\
\text { greater mechanical durability than } \\
\text { polymeric membranes. High cost of } \\
\text { inorganic membranes. }\end{array}$ \\
\hline
\end{tabular}


Table 2. Cont.

\begin{tabular}{|c|c|c|}
\hline Method & Features & Limitations \\
\hline Ultrafiltration & $\begin{array}{l}\text { Removal of colloidal materials and } \\
\text { large dissolved molecules. Pore sizes } \\
\text { range from } 0.001-0.01 \mu \mathrm{m} \text {. Pressure } \\
<1 \mathrm{MPa} \text {. DFs in the region of } 10^{3} \text { for } \alpha \\
\text { and } 10^{2} \text { for } \beta \text { and } \gamma \text { emitters. High } \\
\text { volume reduction factor can be } \\
\text { achieved. Good chemical and radiation } \\
\text { stability for inorganic membranes. }\end{array}$ & $\begin{array}{l}\text { Fouling-need for chemical cleaning } \\
\text { and backflushing. Organic } \\
\text { membranes subject to radiation } \\
\text { damage. Short lifetime of organic } \\
\text { membranes. Inorganic membranes } \\
\text { exhibit greater mechanical durability } \\
\text { than polymeric membranes. High } \\
\text { cost of inorganic membranes. }\end{array}$ \\
\hline Nanofiltration & $\begin{array}{l}\text { Separation of salts with charge } \\
\text { differences and separation of high } \\
\text { molecular weight organics from high } \\
\text { concentration monovalent salt } \\
\text { solutions. Pore sizes between } 0.001 \text { and } \\
0.01 \mu \mathrm{m} \text {. Pressure from } 0.3 \text { to } 1.4 \mathrm{MPa} \text {. } \\
\text { Functions between ultrafiltration and } \\
\text { reverse osmosis, and is often termed } \\
\text { 'loose reverse osmosis'. }\end{array}$ & $\begin{array}{l}\text { Organic membranes subject to } \\
\text { radiation damage. Short lifetime of } \\
\text { organic membranes. }\end{array}$ \\
\hline $\begin{array}{l}\text { Reverse } \\
\text { osmosis }\end{array}$ & $\begin{array}{l}\text { Removes dissolved ions and small } \\
\text { molecules that contaminate aqueous } \\
\text { solutions. } 10<\mathrm{DF}<10^{2} \text {. Well } \\
\text { established for large scale operations. } \\
\text { Compete with other separation } \\
\text { processes (such as evaporation). } \\
\text { Suitable for waste streams with } \\
\text { complex radiochemical compositions. }\end{array}$ & $\begin{array}{c}\text { High pressure system, limited by } \\
\text { osmotic pressure. } \\
\text { Non-back-washable, subject to } \\
\text { fouling. }\end{array}$ \\
\hline
\end{tabular}

${ }^{1}$ DF stands for the decontamination factor, which is defined as the ratio of the initial specific radioactivity of waste to the specific radioactivity of purified water.

The preliminary analysis of treatment methods commercially available has identified the sorption and ion exchange method as the most effective technology to treat the aqueous waste on site (see the pathway selected in Figure 1). The contaminated water treatment (purification) was conducted within the IAEA Technical Cooperation national project GEO9013, involving both local and international experts. Based on the Statement of Work (SoW) jointly prepared by local and IAEA experts and the results of the tender conducted by the IAEA, the Federal State Unitary Enterprise "Radon", Russia, was identified as the subcontractor to complete the works on site jointly with local experts [20].

Modernized manganese dioxide (MDM) [21] and strong acid cationic resin KU-2-8, which is an analog of DOWEX HCR-S resins, were selected as basic materials and tentatively tested to identify the main technological parameters of the purification process. The tests proved an effective reduction of ${ }^{226} \mathrm{Ra}$ concentration using the sorption-ion exchange method, with expected operational lifetime of materials used as follows:

- $\quad$ MDM-100-1000 bed (column) volumes;

- KU-2-8-50-200 bed (column) volumes.

The flow rate used was up to 10 bed volumes per hour.

Based on the SoW and test data obtained a modular facility was devised by FSUE "Radon" similar to [13], which was manufactured so that the technological equipment is housed inside metallic $200 \mathrm{~L}$ drums. The technological scheme of the equipment is shown in Figure 3.

The initial aqueous radioactive waste was pumped out from the first underground tank (IT) and fed to the plant by pump P1, at the flow rate of $0.45 \mathrm{~m}^{3} / \mathrm{h}$. The flow rate was determined by a rotameter at the outlet and controlled by a water meter. The excess of aqueous radioactive waste was dumped back into tank IT via the bypass line, supplied with a valve V1. Adjustment of the flow rate of aqueous radioactive waste through the plant was carried out using valve V1. 


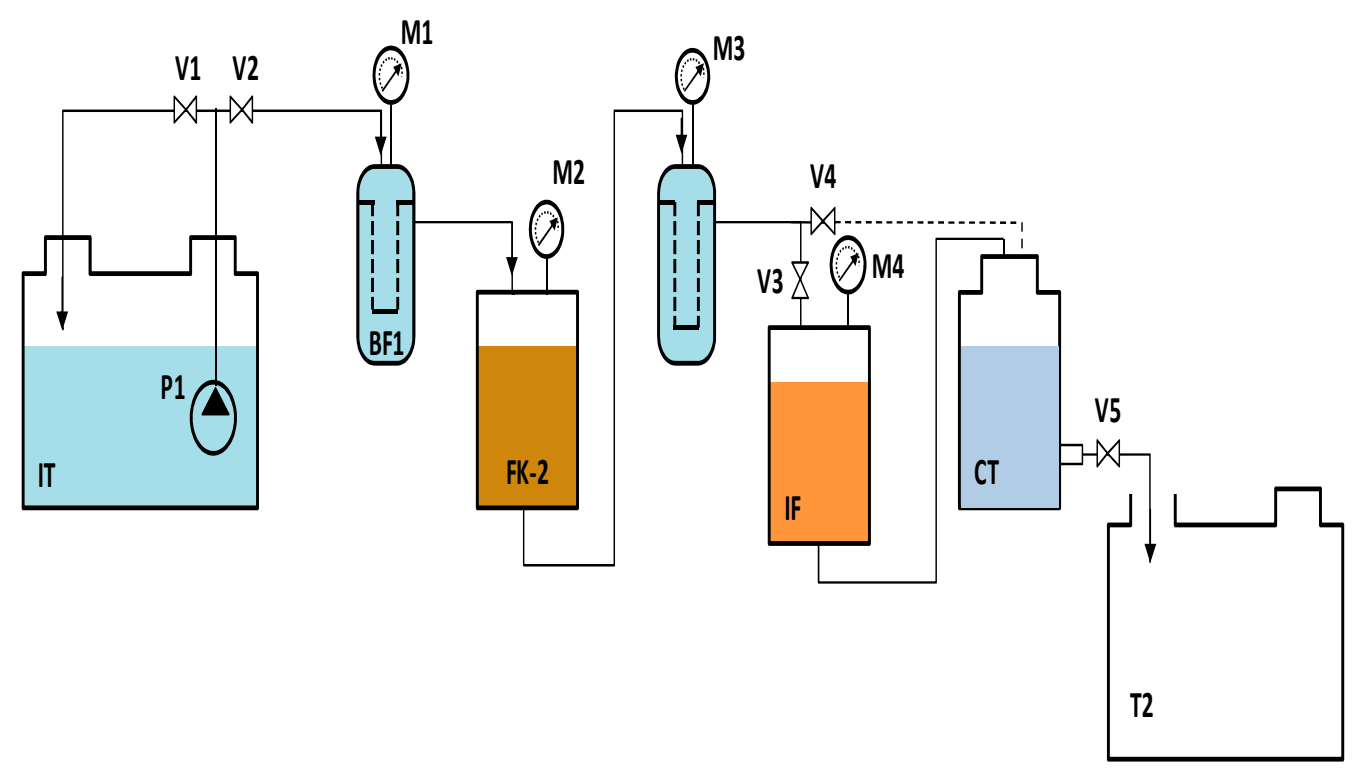

Figure 3. Diagram of water purification installation used on site.

At the first stage of treatment, the aqueous radioactive waste was passed through a bag filter BF1 with pore size of $1 \mu \mathrm{m}$.

Then the aqueous radioactive waste was further cleaned of ${ }^{226} \mathrm{Ra}$ in the filter-container FK-2, containing as sorbing agent the selective sorbent MDM.

The bag filter BF2 with pore size of $1 \mu \mathrm{m}$ was used to further purify the aqueous radioactive waste from suspended particles.

The ion exchange filter IF containing the cation-exchange type resin KU-2 in Na-form was used for purification of aqueous radioactive waste from the ${ }^{226} \mathrm{Ra}$ decay products.

The purified water was collected in the control tank CT. Every 10 hours, representative samples were taken from CT for gamma spectra analysis in the laboratory, using a high purity Ge detector.

The water stream purified was accumulated at the second tank (T2) for its potential use on site, or alternatively for its discharging into the environment following regulatory procedures.

During the treatment work, which lasted 12 days, several replacements of the filtering elements in the filters BF-1 and BF-2 were carried out. During the procedure it was found that the actual volume of the aqueous radioactive waste in the tank was larger than had been initially assessed due to the unexpected shape of the bottom of the tank. The actual volume of the contaminated liquid was $50 \mathrm{~m}^{3}$. After processing of $41.5 \mathrm{~m}^{3}$ of the aqueous radioactive waste, the cleaning efficiency of the filter FK-2 began to decrease. The hydraulic resistance of the filter increased up to $0.1 \mathrm{MPa}$. Therefore, the FK-2 filter was disabled and the ion exchange resin in the filter was replaced. The purification was continued using the BF-1 filter and the IF filter until the first tank containing the aqueous radioactive waste was completely emptied. The bottom sediment in the tank was left in place and thus might require further processing depending on further use of this tank.

\section{Discussion}

During the purification process express analyses were conducted by measuring the radiation levels and radionuclide content in the aqueous radioactive waste passing through the apparatuses by gamma spectrometry means. The first express analysis of cleaned water showed an increased level of beta radiation [22]. Spectroscopic measurement conducted by Falcon-500 at measurement times of 15-30 min identified the increase of radium daughter product ${ }^{214} \mathrm{Bi}$, which has a very short half-life of 19.9 min (Figure 4 ). 


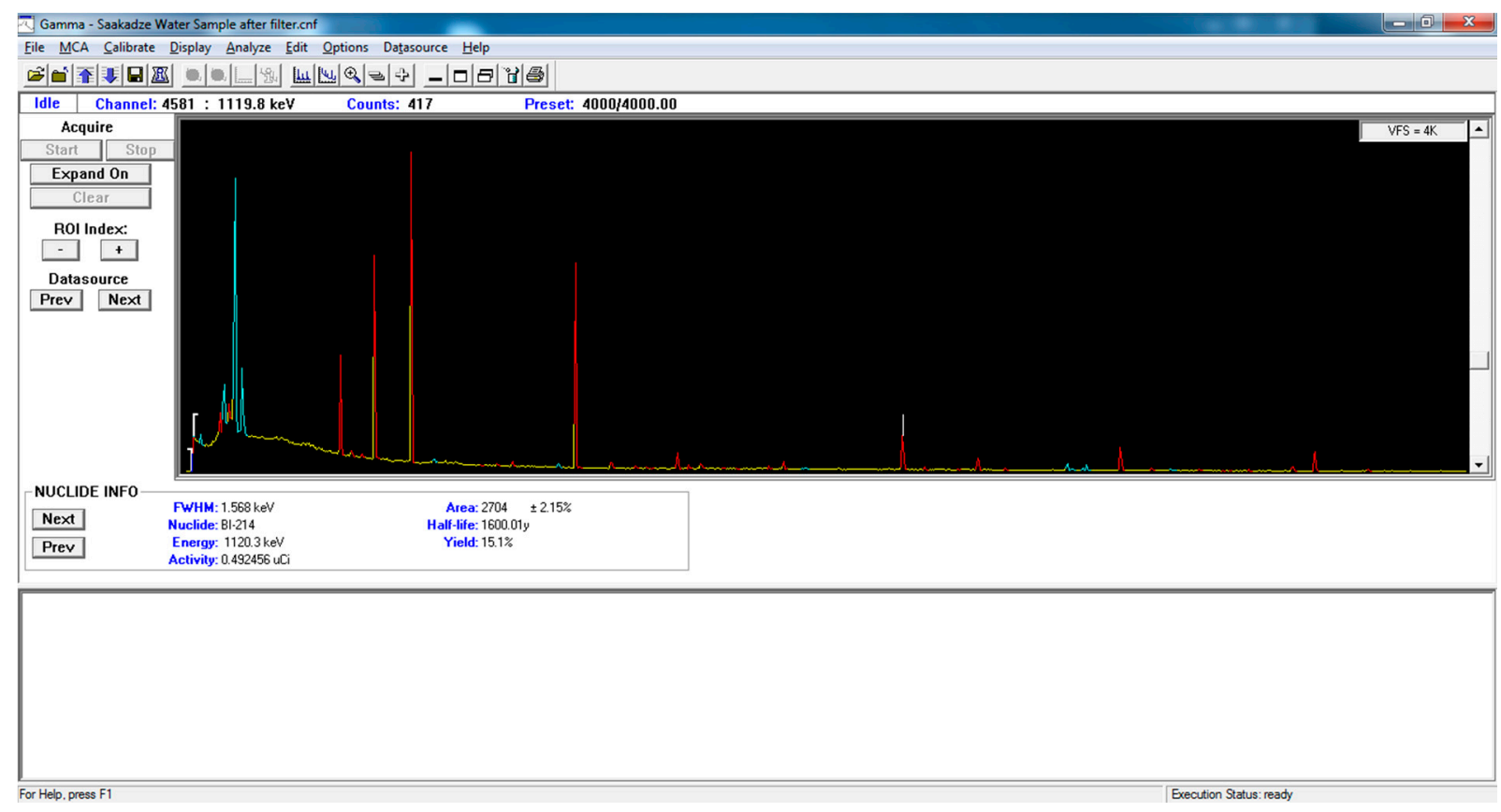

Figure 4. A typical sample of gamma spectra of purified water showing the presence of ${ }^{226} \mathrm{Ra}$ decay product ${ }^{214} \mathrm{Bi}$.

After keeping the purified water for about 2 to $3 \mathrm{~h}$, the radioactivity levels reduced dramatically, as shown in Table 3, which gives data on radionuclide contents in purified water, where the measurement was conducted for $8 \mathrm{~h}$.

Table 3. Radionuclide concentrations in the purified water.

\begin{tabular}{ccc}
\hline Radionuclide & Activity, Bq/kg & Measurement Error, \% \\
\hline${ }^{22} \mathrm{Na}$ & 1.1 & 43 \\
${ }^{40} \mathrm{~K}$ & 15.1 & 95 \\
${ }^{46} \mathrm{Sc}$ & 12.9 & 19 \\
${ }^{109} \mathrm{Cd}$ & 98.8 & 22 \\
${ }^{134} \mathrm{Cs}$ & 1.3 & 39 \\
${ }^{140} \mathrm{Ba}$ & 3.1 & 60 \\
${ }^{140} \mathrm{La}$ & 2.5 & 25 \\
${ }^{143} \mathrm{Ce}$ & 5.7 & 49 \\
${ }^{155} \mathrm{Eu}$ & 13.9 & 19 \\
${ }^{237} \mathrm{~Np}$ & 7.0 & 98 \\
${ }^{226} \mathrm{Ra}$ & $<23.1$ & -1
\end{tabular}

${ }^{1}$ When determining the concentration of radium, only the maximum level is given which is very small and therefore the error is undefined.

These data show that specific levels of purified water are acceptable for discharge and that the water purified can be assigned as clean water acceptable for reuse or discharge.

\section{Conditioning of Secondary Waste}

The following secondary radioactive waste was generated during the processing activities on site:

- $\quad$ spent sorbents;

- $\quad$ spent ion exchange resins;

- $\quad$ spent filter elements;

- $\quad$ pump and piping.

All this waste was immobilized using a purposely prepared cementitious matrix, which is typical for low level radioactive waste immobilization [23]. A significant advantage 
of the equipment used was that its technological elements (shown above in Figure 4) were installed inside prefabricated metallic drums. Therefore, the spent sorbents, ion exchangers and filter elements were not removed from their housings and could be directly cemented inside the drums, see Figure 5.

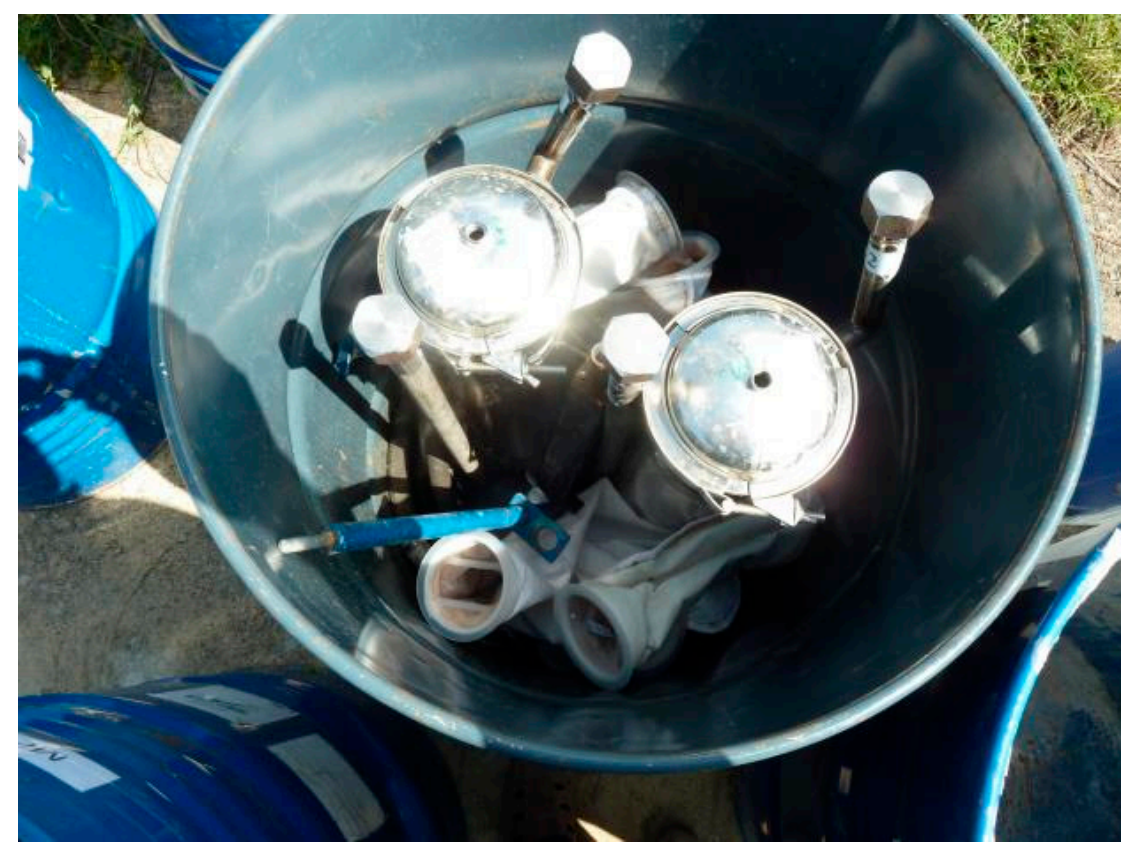

Figure 5. The equipment prepared for immobilization in the cementitious matrix.

The content of ion exchange resins in the cementitious compound was $10 \%$ in terms of dry resin. The water-cement ratio was 0.5 . The spent filter elements, pipelines and the pump were placed in the same drum with bag filters (Figure 5). As a result of aqueous radioactive waste processing, three metallic $200 \mathrm{~L}$ drums containing cemented radioactive waste were produced (Figure 6).

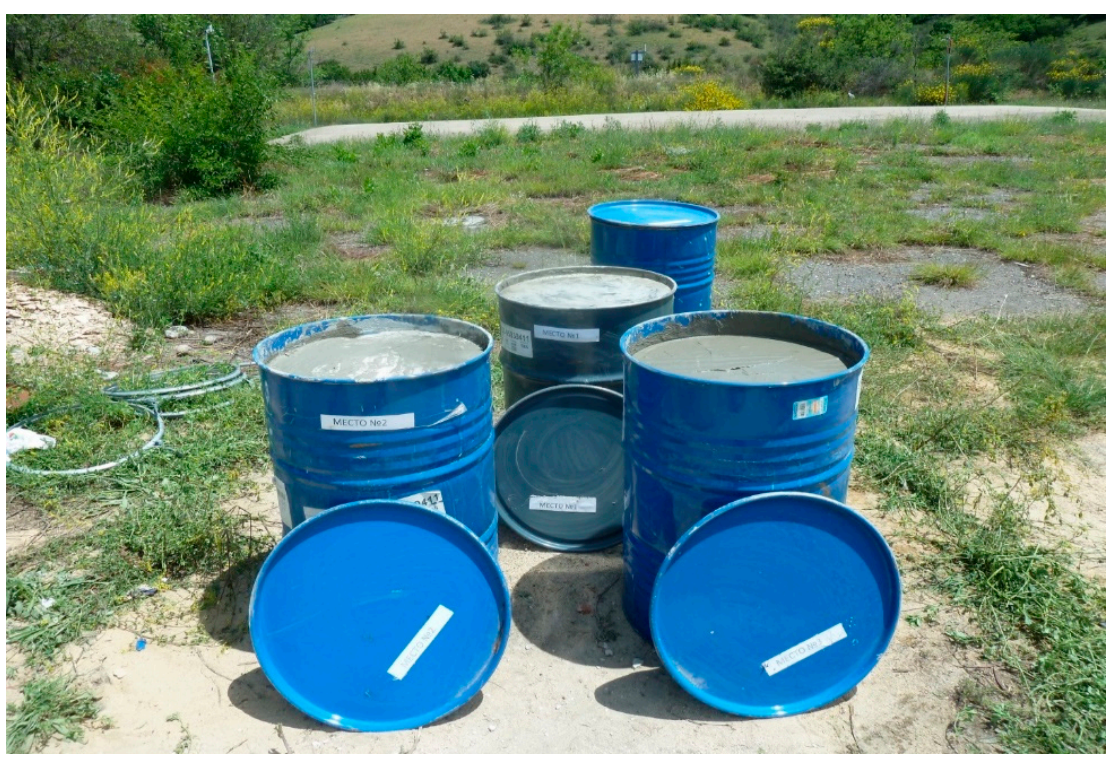

Figure 6. The three drums containing the secondary waste from treatment of $50 \mathrm{~m}^{3}$ liquid radioactive waste immobilized in a cementitious matrix. The fourth drum in the back was used as operational waste collection container during working shifts. 
The drums with conditioned radioactive waste were transported to the Centralized Storage Facility (CSF) for safe storage pending final disposal. The overall volume reduction factor (VRF) achieved through treatment followed by conditioning of waste was thus $\mathrm{VRF}=(50 / 0.6)=83.3$.

\section{Conclusions}

The IAEA-assisted treatment of $50 \mathrm{~m}^{3}$ of legacy aqueous waste conducted at the Saakadze site in Georgia was successfully completed within a month as a result of the important preparatory works, which comprised characterization of waste and identification of the most suitable treatment technologies. It has, nevertheless, revealed that the actual parameters differed from those tentatively assessed: e.g., the total volume of waste processed was $50 \mathrm{~m}^{3}$ instead of the $41.5 \mathrm{~m}^{3}$ assumed. Another unexpected feature was the increased level of radioactivity immediately after treatment, which was due to concentration of the very short-lived ${ }^{226}$ Ra decay product. A positive lesson learned was the organization and successful operation of the international team led by the IAEA.

The treatment of legacy liquid radioactive waste at the Saakadze site has utilized the sorption/ion exchange technology implemented by a prefabricated modular type of facility, which had its parts encased in metallic drums. This form of housing enabled an effective conditioning of all secondary waste at the end of the treatment campaign. The treatment process resulted in the fully purified $50 \mathrm{~m}^{3}$ of water being left on site for further reuse or discharge, and three $200 \mathrm{~L}$ metallic drums with cemented radioactive waste currently in safe storage.

Author Contributions: Conceptualization, M.I.O. and G.N.; methodology, M.I.O.; validation, I.G. and G.N.; formal analysis, I.G.; investigation, I.G.; resources, G.N.; data curation, G.N.; writingoriginal draft preparation, G.N.; writing-review and editing, M.I.O.; supervision, I.G.; project administration, G.N.; funding acquisition, G.N. All authors have read and agreed to the published version of the manuscript.

Funding: This research was funded by IAEA via National project GEO9013.

Institutional Review Board Statement: Not applicable.

Informed Consent Statement: Not applicable.

Data Availability Statement: Data supporting reported results can be found contacting authors.

Acknowledgments: The authors are grateful to the IAEA and local experts Carmina Jimenez Velasco, Zoran Drace, Vasil Gedevanishvili, Yuri Karlin, Alexander Savkin and the late Olga Karlina without whom this work could not have been successfully completed. We are also grateful to the anonymous reviewers of the manuscript whose critical comments and advice improved the paper.

Conflicts of Interest: The authors declare no conflict of interest.

\section{References}

1. IAEA. Selection of Technical Solutions for the Management of Radioactive Waste; IAEA TECDOC; International Atomic Energy Agency, Vienna International Centre: Vienna, Austria, 2017; Volume 1817, 112p. Available online: http:/ /www-pub.iaea.org/books / IAEABooks/12217/Selection-of-Technical-Solutions-for-the-Management-of-Radioactive-Waste (accessed on 18 August 2021).

2. IAEA. Disposal of Radioactive Waste; Specific Safety Requirements; International Atomic Energy Agency, Vienna International Centre: Vienna, Austria, 2011; Volume SSR-5, 62p. Available online: https://www.iaea.org/publications/8420/disposal-ofradioactive-waste (accessed on 18 August 2021).

3. Ojovan, M.I.; Lee, W.E.; Kalmykov, S.N. An Introduction to Nuclear Waste Immobilisation, 3rd ed.; Elsevier: Amsterdam, The Netherlands, 2019; 498p.

4. Chabashvili, M.; Japaridze, G.; Lordkipanidze, S.; Nabakhtiani, G.; Pataraia, T.; Rostomashvili, Z. Georgia's Nuclear Odyssey: The Path from Soviet Atomic Legacy to Global Nonproliferation Regime; Civil Council of Defence and Security CCDS: Tbilisi, Georgia, 2013; 102p, ISBN 978-9941-0-6091-5.

5. EU. Project G.4.01.08 Survey and Strategic Assessment of Georgian Radwaste Disposal and Interim Storage Sites, Technical Report 2.2: Results from the Environmental and Radiological Site Survey; European Union: Maastricht, The Netherlands, 2012.

6. Georgian Technical Regulation No. 450-Radiation Safety Norms and Basic Requirements Related to Handling of Ionizing Radiation Sources; Parliament of Georgia: Tbilisi, Georgia, 2015; pp. 9-10. 
7. IAEA. Treatment of Low-and Intermediate-Level Liquid Radioactive Wastes; Technical Reports Series; International Atomic Energy Agency, Vienna International Centre: Vienna, Austria, 1984; Volume 236. Available online: https://www.iaea.org/publications/ 1337/treatment-of-low-and-intermediate-level-liquid-radioactive-wastes (accessed on 18 August 2021).

8. IAEA. Chemical Precipitation Processes for the Treatment of Aqueous Radioactive Waste; Technical Reports Series; International Atomic Energy Agency, Vienna International Centre: Vienna, Austria, 1992; Volume 337. Available online: https://www. iaea.org/publications/1441/chemical-precipitation-processes-for-the-treatment-of-aqueous-radioactive-waste (accessed on 18 August 2021).

9. IAEA. Advances in Technologies for the Treatment of Low and Intermediate Level Radioactive Liquid Waste; Technical Reports Series; International Atomic Energy Agency, Vienna International Centre: Vienna, Austria, 1994; Volume 370, 117p. Available online: https:/ / inis.iaea.org/collection/NCLCollectionStore/_Public/26/038/26038193.pdf (accessed on 18 August 2021).

10. IAEA. Handling and Processing of Radioactive Waste from Nuclear Applications; Technical Reports Series; International Atomic Energy Agency, Vienna International Centre: Vienna, Austria, 2001; Volume 402, 143p. Available online: https: / / www.iaea.org/ publications /6006/handling-and-processing-of-radioactive-waste-from-nuclear-applications (accessed on 18 August 2021).

11. IAEA. Application of Ion Exchange Processes for the Treatment of Radioactive Waste and Management of Spent Ion Exchangers; Technical Reports Series; International Atomic Energy Agency, Vienna International Centre: Vienna, Austria, 2002; Volume 408, 115p. Available online: https:/ / www.iaea.org/publications/6221/application-of-ion-exchange-processes-for-treatment-of-radioactivewaste-and-management-of-spent-ion-exchangers (accessed on 18 August 2021).

12. IAEA. Application of Membrane Technologies for Liquid Radioactive Waste Processing; Technical Reports Series; International Atomic Energy Agency, Vienna International Centre: Vienna, Austria, 2004; Volume 431, 145p. Available online: https: //www.iaea.org/publications/7029/application-of-membrane-technologies-for-liquid-radioactive-waste-processing (accessed on 18 August 2021).

13. Karlin, Y.V.; Dmitriev, S.A.; Iljin, V.A.; Ojovan, M.I. Elaboration of not large mobile modular installations "Aqua-Express" (300 L/h) for LWR cleaning. In Proceedings of the WM'03 Conference, Tucson, Arizona, 23-27 February 2003 ; p. 8.

14. Karlin, Y.V.; Chujkov, V.Y.; Adamovich, D.V. Liquid radioactive waste (LRW) reprocessing by means of modular mobile plants. At. Energy 2001, 90, 65-69. [CrossRef]

15. Karlin, Y.V.; Chuikov, V.Y.; Adamovich, D.V.; Slastennikov, Y.T.; Il'in, V.A.; Sumenko, A.V.; Flit, V.Y.; Dmitriev, S.A.; Sobolev, I.A. Reprocessing of liquid radioactive wastes using mobile modular systems. At. Energy 2001, 90, 74-79. [CrossRef]

16. Savkin, A.E.; Karlin, Y.V.; Maryakhin, M.A. Development and trials of an improved process for decontamination of liquid radioactive wastes from Radon Moscow Research and Production Association. Radiochemistry 2011, 53, 559-562. [CrossRef]

17. Hung, Y.-T.; Aziz, H.A.; Al-Khatib, I.A.; Abdel Rahman, R.O.; Cora-Hernandez, M.G.R. Water quality engineering and wastewater treatment. Water 2021, 13, 330. [CrossRef]

18. Abdel Rahman, R.O.; Ibrahium, H.A.; Hung, Y.T. Liquid Radioactive Wastes Treatment: A Review. Water 2011, 3, 551-565. [CrossRef]

19. Abdel-Rahman, R.O.; El-Kamash, A.M.; Ali, H.F.; Hung, Y.T. Overview on recent trends and developments in radioactive liquid waste treatment part 1: Sorption/Ion Exchange Technique. Int. J. Environ. Eng. Sci. 2011, 2, 1-16.

20. Savkin, A.E.; Karlin, Y.V. Processing of liquid radioactive waste accumulated in Georgia. In Proceedings of the 1st Scientific Practical Conference "Environmental Protection and Radioactive Waste Management of Scientific and Industrial Centers" (FSUE “RADON"), Moscow, Russia, 24-26 April 2019; pp. 12-18.

21. Dmitriev, S.A.; Adamovich, D.V.; Gelis, V.M.; Milyutin, V.V. Development of a selective sorbent for liquid radioactive waste decontamination from strontium. In Proceedings of the International Conference WM'2005, Tucson, AZ, USA, 27 February-3 March 2005.

22. Giorgadze, I.; Nabakhtiani, G.; Kotetishvili, K.; Chelidze, L. Site Selection for Radioactive Waste Management Facilities in Georgia. Adv. Ecol. Environ. Res. 2020, 5, 276-283.

23. Abdel Rahman, R.O.; Rahimov, R.Z.; Rahimova, V.; Ojovan, M.I. Cementitious Materials for Nuclear Waste Immobilization; Wiley: Chichester, UK, 2015; 232p, ISBN 978-1-118-51200-5. 